Complutense Journal of English Studies

ISSN: 2386-3935

\title{
Dis-Comforting Urban Myths: Challenging Brexit Nostalgia in Recent Edinburgh Fiction
}

\author{
Carole Jones $^{1}$
}

Abstract. This article analyses two contemporary novels, Mary Paulson-Ellis' The Other Mrs Walker (2016) and Ever Dundas' Goblin (2017), comparing their depictions of Edinburgh in their strikingly similar parallel narratives, in which a contemporary Edinburgh setting intertwines with that of London in the Second World War. In the context of the Brexit vote of 2016, in which arguments for British autonomy and border closure won the day, the article argues that these texts challenge the pro-Brexit discourse which employed the mythology of the Blitz spirit to undermine the backward-looking nostalgia of a specifically English nationalism. In contrast, the Scottish setting of Edinburgh is presented here as facilitating a turn to a future of more mobile narratives of interrelation and connectedness rather than the fixed dimensions of myth.

Keywords: Edinburgh fiction; Mary Paulson-Ellis; Ever Dundas; Brexit; Blitz spirit.

[es] Mitos urbanos in-cómodos: la refutación de la nostalgia del Brexit en la ficción reciente de Edimburgo

Resumen. Este artículo analiza dos novelas contemporáneas, The Other Mrs Walker (2016), de Mary Paulson-Ellis, y Goblin (2017), de Ever Dundas, comparando sus representaciones de Edimburgo a través de unas narraciones sorprendentemente similares y paralelas, en las que el Edimburgo contemporáneo se entremezcla con el Londres de la Segunda Guerra Mundial. En el contexto de la votación del Brexit de 2016, en el que triunfaron los argumentos a favor de la autonomía británica y el cierre de fronteras, el artículo defiende que estos textos cuestionan el discurso pro-Brexit que se sirvió de la mitología del espíritu del Blitz para socavar la nostalgia retrógrada de un nacionalismo específicamente inglés. Por el contrario, el escenario escocés de Edimburgo se presenta como facilitador de un giro hacia un futuro de narrativas más móviles de interrelación y conectividad, opuesto a las dimensiones fijas del mito.

Palabras clave: ficción de Edimburgo; Mary Paulson-Ellis; Ever Dundas; Brexit; espíritu del Blitz.

Contents: 1. Introduction. 2. The Other Mrs Walker. 3. Goblin. 4. Conclusion.

How to cite this article: Jones, C. (2021) Dis-Comforting Urban Myths: Challenging Brexit Nostalgia in Recent Edinburgh Fiction, in Complutense Journal of English Studies 29, 17-24.

\section{Introduction}

This article reflects on the significance of depictions of Edinburgh in two recent novels, The Other Mrs Walker by Mary Paulson-Ellis (2016) and Goblin by Ever Dundas (2017). In an intriguing correlation, both texts consist of strikingly similar parallel narratives; a contemporary Edinburgh setting intertwines with that of London around the Second World War. This structure raises questions about the texts' relation with the historical moment of their publication, which is close in proximity to the UK referendum of 2016 on leaving the European Union, which I will address in due course. Alongside the temporal juxtaposition of the narratives, the urban spaces of their settings are in constant flux. Although this can be expected in the context of war, these spaces are also dynamically transforming according to the changing relations of their inhabitants, power shifts that can have consequences for those groups marginalised from power, illustrated in the dangers for women when, for example, domestic spaces are repurposed for sexual exploitation and illicit practices. The novels foreground the unhomeliness of these urban spaces. Relatedly, the texts bring into question certain mythicising affect narratives of these cities, which continue to permeate contemporary political discourse - the cold, dour reserve of the northern city of Edinburgh and the Blitz spirit of London in wartime. Such myths can be seen in terms of what Doreen Massey describes as "attempts to institute horizons, to establish boundaries,

Department of English Literature, University of Edinburgh

ORCID: 0000-0002-3679-7336

Email: Carole.Jones@ed.ac.uk

Complut. j. Engl. stud. 29 2021: 17-24 
to secure the identity of places"; really, she argues, these are "attempts to stabilize the meaning of particular envelopes of space-time" (1994: 5) in the cause of specific power relations. These city-based myths tap into national narratives and they resonate with significance, evoked at a moment of widespread anxiety regarding Britain's stability, status and place in the world. The novels of Paulson-Ellis and Dundas complicate and undermine these myths, and in doing so they assiduously posit the openness of the Scottish context in a period of increasing concern globally with strengthening boundaries and closing borders.

\section{The Other Mrs Walker}

Edinburgh does not suffer from a lack of representation in literature; its portraits are multiple, diverse and often lively. As an urban space, its instability is demonstrated by Caroline Jones' mapping of the city in the later twentieth-century fiction of Ian Rankin, Irvine Welsh and Alexander McColl Smith, where Edinburgh is "in a state of constant flux" (2015: 56). It is significant, then, that Paulson-Ellis's The Other Mrs Walker appears to evoke an older city fabled for its conservativism before the latter decades of the twentieth century. The Scottish capital is ambivalently memorialised by its twentieth-century writers who often veer between affection and irritated repulsion at its narrow social proprieties, the people with "predestination in their smiles", as Muriel Spark's Jean Brodie caustically observes (2000: 75). For writer and editor Karl Miller too, the city before the Second World War is "prim", full of "reverend seniors, with a mercantile middle class that has seen better days and a petty-bourgeoisie given over utterly to primness" (1970: 95). Also suffering from this primness, Muriel Spark is "an exile in heart and mind" from the city (Spark 1970: 152), but is more philosophically paradoxical; she is "cautious, affectionate, critical. It is a place where I could not hope to be understood (...) Nevertheless, it is the place where I was first understood" (Spark 1970: 152). This "nevertheless" city, embodying the contrary nature of that politely antagonistic word, imparts a "haughty and remote anarchism" (Spark 1970: 153) to Spark and her writing. It suggests a contradictory waywardness that characterises the city as, to a great extent, ungraspable and mobile, a place mischievously insistent on the reversible changeability of certainties. Ultimately substantiating such perceptions, The Other Mrs Walker challenges the singularity and stability of space as expressed in Edinburgh's prim reputation and presents the city in dynamic relation with its past, its present and its people.

It can be argued that this challenge is potentially denied by the text's ostensible reproduction of that socially frigid Edinburgh with its "grey skies, grey buildings, grey pavements all encased in ice" (2017: 7). Inner and outer space here is close, stifling and claustrophobic: streets are "narrow chasms" (2017: 77), flats are in "dark tenements [with] dirty windows" (2017: 115), office premises are "labyrinths" (2017: 51) and homes are shrunken with "box rooms" and "that tiny square of beige her mother called the hall" (2017: 13). Moreover, the city that central character Margaret Penny returns to in mid-life is synonymous with death; it is embalmed in a deep freeze "as though the whole of Edinburgh was sleeping or dead (...) godforsaken" (8); the people are grey, "their faces all gone to ash in the unrelenting cold" (2017: 3); Margaret's mother greets her with "a face already marked by the pallor of a corpse" (2017: 9). The city itself embodies this state: "The black monoliths of Edinburgh were passing: castle (ancient); volcano (dead); finance quarter (wounded)" (2017: 38), while the council offices are a "palace of death" in the "dead centre of town" (2017: 51). Full of the old, the dying and the expired, Edinburgh is unresurrected, a mausoleum that is "a land of secrets that everyone knew but pretended they did not" (2017: 17). Margaret's repeated slight of this staid formality - "that would be the Edinburgh Way" (2017: 31) - is her dismissive rejection of the city's inflated and eternally fixed proprieties.

Nevertheless, The Other Mrs Walker is a novel in constant movement resisting this fixity on a stylistic level. There are parallel plots here, set in contemporary Edinburgh and before, during and after wartime in London, and the narrative jumps between them in alternating sections headed by the year. Although these are ostensibly discrete chapters transitioning cleanly from one period to the other, they are often clearly linked and bridged with significant words and images. For example, at the end of the first section which focuses on Margaret's first night in Edinburgh, she finds in her coat pocket "the last of her Christmas clementines, borrowed from a market stall in London" (2017: 17). On the next page, the section headed "1929" begins with "a small orange sun", a similar fruit, rolling from Albert Walker's sleeve to the delight of his daughter named Clementine. A "1953" section ends with "London was rising. Washing itself clean" (2017: 142) and the very next "2011" section begins with the echoing "[t]he very next morning, up early with the rise", though it morbidly plays with this movement by continuing "and Margaret Penny returned to the territory of the dead" (2017: 143). This frequent mobilising and linking of words and images spans the gaps between sections and this penetrating of textual borders continues in the richly connotative prose that proliferates meanings beyond the bounds of the text. For example, when Barbara is caught in the vicinity of an airstrike in war-torn London, she experiences "dust rolling across the ground towards her like an enormous desert storm" (2017: 404), a phrase which brings to mind a very different twentieth-century conflict, the "Gulf War" of 1991, which was code named "Desert Storm". Suffused with such proliferating associations, Paulson-Ellis' prose draws attention to its own artfulness and artifice; it is, then, richly expressive, transporting the reader through seductive inter- and intra- 
textual connections that push back at the spatial and temporal confines of the narrative. The novel in fact begins with such an interpenetrating image of spilled whisky seeping between spaces, "down through the fibres of the carpet, down through the rough and dusty floorboards, down to the ceiling of the flat below. It evaporated as it went, leaving nothing but a stain" (2017: 3). This leaking of the "water of life" between apartments and the inscrutable evidence left behind is an evocative premonition of the structuring of the novel, organised as it is around a series of objects transported and resonating between spaces and periods, "The Orange", "A Brazil Nut", "An Emerald Dress", "A Photograph", and the ever-present "Six Orange Pips Sucked Dry". These five overarching sections frame and inform the mystery Margaret must solve.

In these leaking, seeping, echoing and proliferating writing strategies, The Other Mrs Walker challenges the stereotype of an eternally fixed Edinburgh in its destabilising and constantly mobile narrative structure and prose. The saturating of these urban spaces with affective resonance takes the novel further in enabling a challenge to the boundaries of the self in space, evoking subjects in complex relation with their environments. Edinburgh's mummified and mournful aura - in each flat "a thin layer of melancholy coating everything" (2017: 117) — is matched by the austerity and danger of wartime London in a complicated and convoluted plot. This begins with the death of an anonymous elderly woman in Edinburgh and ends with her funeral after her life has been excavated from its origins in London. The person tasked with unravelling this story, and the link between the narratives, is Margaret Penny, returning in penury to her mother Barbara in Edinburgh after thirty years of separation and failures in life and love in London. Struggling for money she is tasked, on the tipoff of an acquaintance of her mother, with a job for the City Council - finding out the identity and possible family connections of the dead woman in order to dispense worldly goods and claim funeral expenses. Unwittingly, Margaret will uncover the story of her own family, which is the subject of the parallel London plot.

This other narrative is not so much Margaret's story but that of her mother Barbara. In effect, it is the troubled unconscious of the novel, the repressed origins of Margaret's life. In Second World War London, death is not metaphorical as the deadly destruction of the conflict marks everyday life: "in front of her, the neighbours' house had vanished into dust. And the neighbours too" (2017: 176). The volatility of the landscape compares sharply with Edinburgh's ostensibly frozen façade. Moreover, the unstable metropolis shakes loose the social relations that cement in place the social hierarchy, creating vacuums that are both physical and psychological; the last we see of Barbara's father Alfred Walker he is "at the point in the road where later a bomb would fall, leaving a crater that took years to be filled" (2017: 96), suggesting a bombed out spirit as well as a street. Alfred's affectionate presence is replaced by Mrs Penny, a woman sent by the midwife to help out the troubled family. With her shady partner Tony, she appropriates the family home and the children when Dorothy, their mother, is sent to an asylum. The Walker children, Clementine and younger twins Ruby and Barbara, become the Penny children, a disruption to kinship relations facilitated by the chaos of the war. However, rather than nurtured, the children become pawns in a setting of exploitation worthy of Dickens in Tony's black-market activities: "'Make a fortune in a war. All those soldiers.' He watched Clementine's bare legs as she made her way out into the hall. 'We could call it the Penny Family Business"' (2017: 102). Tony's entrepreneurial ventures in "Girls and Booze and Cigarettes and Rum" (2017: 163) exist alongside the "houses for desperate women" (2017: 201) that provide back-street abortions at least until its legalisation in 1967 (Ruby works in one such domestic set up before Mrs Penny also turns their home into one), closing the circle of networks of manipulation and exploitation that make the city an even more dangerous and unhomely place for women. Such stories are often suppressed by dominant and popular histories of the London of the time, in which the Blitz spirit and Cheerful Cockneys characterise the rough heroism and moral superiorism expressed in heightened solidarity, neighbourliness and instances of selfless sacrifice. Echoing alternative accounts of this period which detail increased crime rates-from opportunist thefts and looting of bombed out property to sexual assault and systemic persecution of racial and ethnic minorities (see Ponting 1990; Panayi 1995) Paulson-Ellis gives expression to unedifying aspects of wartime London, countering the dominant Blitz spirit myth.

Rather than solidarity, the war and after are times of great betrayal in the novel, specifically in Mrs Penny's requisition and exploitation of the Walker family, but also significantly in Barbara's own actions in relation to her twin sister. After a wild and indulgent youth, Ruby, unmarried, pregnant and suffering a breakdown, is sent to an asylum and gives birth there while she is drugged and vulnerable. Barbara takes her baby girl and disappears with her, eventually settling in Edinburgh where the child, Margaret, grows up with this cold, closed and distant mother. This betrayal of her sister haunts Barbara who, by the time Margaret returns in 2011, dreads answering the door for fear of the past catching up with her. The dead woman Margaret is tasked with investigating is of course Ruby, her own birth mother. However, there are further Dickensian twists to the narrative before it can conclude. Clementine, the older sister thought killed in the war, turns up at the funeral all the way from the US, where she has lived her life growing oranges, and the sisters confront each other, the situation potentially offering Margaret her own denouement. However, with its usual playfulness, the narrative turns away from this moment; though Margaret realises the dead Mrs Walker had come to Edinburgh to see Barbara, the full realisation of the situation is not expressed by the text-Margaret is called away from spying on "the two old women, bending their heads together now to speak in whispers" (2017: 425). In the Epilogue, 
Barbara appears to maintain the story of her natural maternity when she hands Margaret the photograph of herself holding Ruby's baby taken on the day she abducted her. Margaret "gazed at the photograph, something inside her shifting. A mother and her baby, in her hands at last" (2017: 434). What is important here, the novel's closure seems to suggest, is reconciliation with " $a$ mother" if not "the mother". Margaret is left in the interstices of knowledge, suspended between knowing and not knowing her origins. This ambivalence does not pass judgement on the lies and extortions of the past, on the cold and confused and negligent mothering relations of the narrative. Origins are not the most important issue here; this inbetween state enables a turn to the future. The "box" room, with its connotations of a coffin which had symbolised an end to Margaret's life on her arrival in Edinburgh, is transformed in the Epilogue into a daybed; the room appears "to increase in size" (2017: 431) as it is emptied of junk, providing a now liveable space, still liminal but more positively open in its affective potential.

Margaret's life, then, is in process at the close of the narrative, just like the city; green shoots illustrate that "spring is rampaging all over Edinburgh" (2017: 432) and urban spaces are also in transition. In the course of her investigations, Margaret had occasion to visit the dead Mrs Walker's flat and meet her neighbour Pati, the only person who has any familiarity with the dead woman. If the deceased's flat is one frozen and vacant with trails of cold cigarette ash and nineteen empty whisky bottles lined up in the kitchen, Pati's accommodation is its diametrical opposite. For Margaret, "it was like falling down a rabbit hole and ending up in a whole new continent":

It was muted lampshades, soft furnishings and rugs on all of the floors. There were candles on the mantelpiece (...) an ashtray with Welcome to Bratislava written around the rim. There were several collections of Russian matryoshka dolls clustered on the sideboard in small family groups. And flocks and flocks of tiny wooden animals, all polished and smooth (...) Jasmine and frankincense. Sandalwood and musk (...) the entire flat smelling of cumin and paprika, the heady scent of cardamom seeds and garlic (...). In fact, it was rather like the place Margaret had always imagined she might live. (2017: 149)

Pati, or Patrycja, is a Polish migrant, "a member of an Edinburgh Margaret had never known. Cosmopolitan, multilingual, prepared to work hard for a whole new existence and a handful of cash" (2017: 153). Margaret envies her comfort, the warmth of her home, the "million relatives" Pati is surrounded by in the photographs on her mantelpiece. This living room is not part of the "silent unforgiving city in the north" (2017: 223), but a newly wrought space of colour, perfume, warmth, kindness and sociality, open to continents of otherness. But this is "home, I suppose, now", says Pati, emphasising that this, too, is Edinburgh. There are other moments of openness in the novel: the dead Mrs Walker's funeral "is like something out of New Orleans" (2017: 377); the Evangelical Pastor MacDonald shines "rich and earthy in the grey light of Edinburgh" (2017:377) with his choir singing songs "about Jordan and its river (...) calling them hymns didn't seem quite appropriate" (2017: 383); "in every corner of the tiny, heaving space, people were smiling and chatting and shaking hands (...) Pati laughing and talking somewhere in amongst the throng" (2017: 378-9); "representatives of all the city's faiths (and none), gathered together for a celebration of some unknown person's life" (2017: 380).

This vibrant ending, as with Margaret's reconstituted relationship with her mother, shows Edinburgh in a new light, countering with images of openness and hospitality the myth of an unmodern, cold and prim city, suspended and immobilised in a cheerless and unsociable past. Meditating on her own indigent history with her mother in numerous dingy rented apartments, Margaret reflects that "it had taken her a long time to realize that the melancholy didn't come with the flat. It travelled with her" (2017: 117). The text suggests here a "nevertheless" moment, a reversal of opinion; it is not the city that is melancholic, but Margaret and her mother. However, such a re-privatising of emotion to the realm of the individual is challenged by the mobility of the text as it bridges and blurs the gaps between spaces and people, as it similarly blurs the gaps between chapters. Characters are in constitutive relation with the space they inhabit, like Pati with her warm and hospitable home and self. Edinburgh is changing; set in motion in the liminal region between certainties, both Margaret and the city are in process.

\section{Goblin}

The eponymous central character of Dundas' Goblin is also an incomer to Edinburgh, settling in the city as an older woman and discovering the openness of its margins. This narrative, too, travels between Edinburgh in 2011 and London in World War Two; although Goblin has led a peripatetic life, London, the city of her birth, is the most significant location in her history. In contrast with the characters of The Other Mrs Walker, here the act of memory is a conscious process as Goblin writes her memoir in order to understand the direction her life has taken. In each chapter the past and present sit side-by-side; the past emerges in the present, unlike the separated chapters of Paulson-Ellis' novel. Goblin is a record of a life framed by trauma, and the mechanisms of its repression. 
The narrative begins with reference to the discovery of a camera, among other strange objects, buried at a building site in London; media reports date it to World War Two, and the newly developed film reveals events from that time, in particular it seems, scenes of the "pet massacre" (2017: 1). This only recently examined phenomenon took place at the beginning of the war, when many pets were put down by owners either to save them from the trauma to come or to evade the necessity of feeding them (see Kean 2017). This is central to Dundas' novel, making it a text that is once more engaged with the repressed history of London in wartime. Goblin's memories of that time begin to be interspersed in the narrative in these early pages, and it is eventually made clear she is writing her life story: "I must bring order (...) this is the past, this is my story of the war, of London; the realm above, the realm in-between, the realm down below" (2017: 22). Writing to bring order to her memories, Goblin is "a storyteller. I control the past" (2017: 21).

Born in London before the war, Goblin is unwanted and unloved by her mother, who refers to her as "Goblin runt born blue" (2017: 5); hence her name. She does, however, have a loving and affectionate relationship with her older brother David and her dog named Devil. During childhood adventures with friends on the work sites and rough ground of the neighbourhood, the internal marginal spaces of the metropolis, Goblin witnesses two traumatic events that are forever connected in her psyche. Evidence of the pet massacre is caught in a photograph of a mound of dead animal bodies; "some of the bodies are in sacks, but others are piled on, legs in a tangled mess, heads drooping" (2017: 61). Her friend Mac falls over and lies "sprawled in a cushion of fur, cat and dog legs sticking out, giving him new limbs, heads sprouting from his shoulders (...) a monster" (2017: 63). Fantasising a Nazi plot, they return to the site to find this enemy but instead encounter a local gang of youths torturing a victim. It is only at the end of the novel that Goblin is able to realise and admit what she saw and photographed in that moment:

My brother was on his knees and Jack had a gun to his head.

They all flicked on torches, focussing the light on David. They moved in, turning the torches on themselves, creating floating skulls. They all had a dead pet hanging round their necks like stoles. Simon kept his torch pointed at David's face. The sun was descending, the clouds clearing as it sank down into the horizon, casting shadows and a strange orange glow across the scene (...).

I raised the camera and we fell like Alice down the rabbit hole, tumbling in the darkness (...). In a moment, in a second, with a click, it was over. I had pressed the camera shutter, Jack had pulled the trigger, David fell. (2017: 277-278)

In the following chaos, Devil is killed and Goblin buries him in Kensal Green Cemetery along with the camera and other personalised tokens. This is the bundle that is found and making the news in 2011. Both events resurface in the photographs stored in the camera's undeveloped film. This rediscovered memory ends a lifetime of denial for Goblin: "I'd witnessed his death, I'd taken a photograph of the exact moment, but I wasn't sure what I'd seen. The light was fading, it had happened so quickly. I blocked it out and buried the camera, the only thing that could make it real" (2017:278).

Goblin has denied the fact of this murder throughout her life. At the time, she becomes dissociated, hallucinating a ghostly Queen Isabella, Amelia and Scholler, characters introduced in the stories of the Crazy Pigeon Woman who Goblin befriends earlier in the narrative. Also, she makes an occult token, a totem or magic familiar consisting of a shrew's head, dolls leg, and other juxtaposed pieces. This "Frankenstein's monsta" (2017: 70) is the sepulchral sign of the repressed trauma which emerges again with the photographs - a "pretty monsta dead thing. And dead things can't die" (2017: 71). Running away, first as an evacuee to Cornwall, and then all over Europe as a circus performer, Goblin continues to look for her brother, pasting "Have you seen this man?" posters wherever she goes. The forced remembering, then, exposes a trauma that must be approached gradually and obliquely, through the meandering narrative of Goblin's nomadic history prior to her settling in Edinburgh, before it can be belatedly represented to, and admitted by, the self.

The intimate connecting of David's murder with the pet massacre gives it meaning beyond a personal event; this is part of a collective trauma that is not simply the product of the war. David is killed because he is different, bullied by the gang for being "one of them" (2017:25), a familiar euphemism for "homosexual"; he is a victim of murderous homophobia. Killed with the animals, and like an animal, "he went down below with the pets, cradled in their paws, resting on their fur" (2017: 279). Though David is dehumanised by his attackers, Dundas here challenges this denigration of the queer. Animals in this novel have an equality with humans; for Goblin they are the most intimate family and friends, worthy of reciprocal trust and respect. Stuck on her own in London after her parents have died in the war, Goblin makes her home a sanctuary for strays; they live with her, share food and perform with her in her busking routine. We are further led to understand that Goblin is at home in the circus, living side-by-side with other performing animals in a mutually constituted socially marginal location. David's association with the massacred animals, then, enhances his humanity in Goblin's eyes and is a mark of respect, an embrace of otherness that characterises the whole novel.

These hidden histories are located in the marginal spaces of the urban environments of the text: rough ground and work sites; the cemetery; bombed out and defamiliarized streets "deserted. When someone walked 
by, their footsteps echoed. They'd brush past us, a shadow, an apparition" (2017. 59). Foreshadowing Goblin's own haunting by the characters of her imagination, these ghostly spaces signal to repressed histories and, as in The Other Mrs Walker, undermine the dominant narratives of Britishness, and specifically Englishness, built on the image of the moral and kindly nation; the pet massacre "isn't a nice story, it doesn't fit with this notion of us as a nation of animal lovers" (Kean 2013). However, more provocatively, it turns out that David's murderer is now a "91-year-old War Hero", and his prosecution is a source of anger and denial for the nation. This train of events puts into question the comforting national myths of the Second World War, and who it is that counts as part of those narratives.

Significantly, in the novel, the photographs exposing the story emerge at a moment when London is again on fire in the riots of 2011; once more, "I walk the streets and see the ghosts of the buildings that haunt this city" (2017: 143). This time, though, it is not war with a foreign power that destroys London, but the police killing of a suspect, black Londoner Mark Duggan, in controversial circumstances. Riots spread throughout the large urban conurbations of England exposing race and class tensions, as well as economic decline in the wake of the global financial crash of 2008. The distance between those inside and those outside certain social boundaries, who counts and who does not, remains crucially in question.

In contrast, Edinburgh is presented through its civic spaces (the Central Library where Goblin works), its arts festival, and its hospitality - Goblin's adopted father dies here, in his adopted city, not unknown like Mrs Walker, but mourned by a small yet open community of friends. As in Paulson-Ellis' novel, then, Edinburgh here is an open, hospitable city holding the past and present in balance. Difficult histories emerge but do not overwhelm the present; those like Goblin and Margaret who explore "the realm in-between" of repressed memory find a liveable space that is cognizant of ambiguous histories and moral ambivalence, and indulgent of the "nevertheless" turn.

\section{Conclusion}

The Other Mrs Walker and Goblin are uncanny in their parallels. They focus on the unhomely spaces of Edinburgh and London in which unloved protagonists must persist into adulthood through the survival tactics of the hunted and haunted. Clementine, Ruby and Barbara must negotiate the public and private spaces of World War Two London, where for women the danger exists in both the bombs in the streets and the domestic environment, which is repurposed for a sexually exploitative black market and for the practice of illegal abortions. Barbara's act of betrayal in stealing her sister's baby haunts her and fear and anxiety disable her capacity to express affection, making her daughter Margaret also the subject of an enveloping and discomforting melancholy. Goblin, unloved by her mother, survives on the bombed out streets of London by expanding rather than narrowing her realm of affection; the unhomely domestic space here becomes a sanctuary for a constructed family of animals serving as companions, colleagues and fellow travellers through the war-torn environment in contrast with the highlighted pet massacre. These relations persist with other animals in other environments throughout Goblin's life; being fluid in her gender as well as her human identity — as a child most people think she is a boy-Goblin avoids the pressing dangers of exploitation detailed in The Other Mrs Walker, and is at home on the queer margins of society. That both narratives end in an Edinburgh that is relatively open and hospitable to strangers and those on the margins raises suggestive questions regarding their relation to the socio-political moment of their production.

The proximity of the novels' publication to the moment of the UK referendum on membership of the European Union, or the "Brexit" vote, has significant resonance in relation to the focus of the urban settings in their narratives. These texts engage critically with what has become a momentous historical event in such a manner as to constitute a critique of a major current of pro-Brexit political discourse: the promotion of a nationalist mythologised narrative of a heroic, stand-alone and self-sufficient English-dominated British past. Robert Eaglestone describes the persistence of references to the Second World War as an "affect-memory" (2018: 96), a collective shared mood which is focused on the past and, in this case, constitutes a "cruel nostalgia" (2018: 96) - cruel because it distracts from our present predicament and negatively impacts on our ability to resolve it, captivated as we are with myths of uniformity and self-reliance. These narratives, as employed in discourse and imagery by those campaigning to leave the EU, engaged with the "great triumphs of English arms on continental Europe" (O’Toole 2019: 183). For instance, Jacob Rees-Mogg at the Tory Party conference in 2017 exclaimed: "We need to be reiterating the benefits of Brexit! ... Oh, this is so important in the history of our country ... It's Waterloo! It's Crécy! It's Agincourt! We win all these things!" (qtd. O'Toole 2019: 183). In this context, the Second World War specifically provided many opportunities to define the indomitable essence of the British people; for example, as in the headline "Jeremy Hunt warns EU a bad Brexit deal will stir Britain's 'Dunkirk Spirit" (Daily Telegraph, 30 September 2018). The "Dunkirk spirit", referring to the evacuation of Allied soldiers from northern France in 1940, exists alongside the Blitz spirit that characterises the positive coping and survival strategies of Londoners in the early stages of the war. This particular pithy phrase has continued to inform popular analysis of the actions of plucky Britons 
in tricky circumstances, that they are imbued with Blitz spirit. I contend here that Paulson-Ellis and Dundas present a critique of this backward-looking political narrative and the ideological messages it is promoting by comprehensively undermining the myth of the Blitz spirit in their representation of London during the war. And they do this from the standpoint of Edinburgh, a city with its own ambivalent history that is currently seeking, along with Scotland and the people living there more generally, a place of greater openness and interconnection in the post-Brexit landscape. Significantly, Scotland voted substantially to remain in the EU in all areas of the country.

The notion of the Blitz spirit is a familiar structure of feeling, in Raymond Williams' words, informing how the British have viewed themselves since the war; it emerges from "the Blitz", the period of heavy sustained bombing of London and other British cities in 1940-1941. The unprecedented loss of life and destruction necessitated heightened strategies of survival and resistance, with London setting the paradigm in media and government communications of the time. The "figure of the Cheerful Cockney" and the bravery, neighbourliness and "good, gutsy, orderly" (Calder 1991: 30) solidarity of Londoners became the dominant narrative of this time, necessary for the purposes of strengthening the morale of the British people generally in a time of warfare. Darren Kelsy has argued in his analysis of media discourse in the wake of the " $7 / 7$ " terrorist attacks in London in 2005 that such ongoing discourses are an example of "'national narration' that evoke national consensus through memories, stories, rituals and traditions from the past" (2013: 84). The Blitz spirit is just such an enduring resource for expressing the essence of national identity and as such it was from the beginning "mythologised" (Calder 1991). Kelsy points out that "historians have reviewed the Blitz spirit as a myth; not as a lie about Britain's past, but a simplified version of events that suppresses less popular memories of the situation in Britain at the time", ignoring the "complexities that transcend and often conflict with a preferred version of events" (2013: 84). In contrast to the Brexit leave campaigners' appropriation of the heroic associations of such mythologised narratives, the Paulson-Ellis and Dundas novels give space to the complicated repressed histories that undermine those dominant images. In this they are, in effect, rejecting the premises of the anti-Brexit campaign that Britain has always triumphed and benefits by standing alone in the world. They are also rejecting the construction of the metropolis as a beacon of progressiveness- "the London that was during the Brexit debates claimed as a beacon of cosmopolitanism" (Gardiner 2018: 111) - in comparison with the image of the Scottish capital as a provincial backwater.

However, in their parallel structures, which foreground the contemporary location of Edinburgh, there is no simplistic opposing of this unsettling characterisation of London with a stable and progressive rendition of the Scottish capital; in some ways, it continues to be a dark and alienating place that is socially and physically difficult to navigate. The comparison does, though, promote reflection on the overly binarized fixation with borders - between us and them, insiders and outsiders - dwelt on in the pro-Brexit arguments, and posits the Scottish context as a locus for challenging and critically questioning the provenance and stability of physical, metaphysical and discursive boundaries, promoting the necessity of social openness in increasingly divisive times. Edinburgh in these texts is an example of Massey's "open and porous" places:

The identities of place are always unfixed, contested and multiple. And the particularity of any place is, in these terms, constructed not by placing boundaries around it and defining its identity through counter-position to the other which lies beyond, but precisely (in part) through the specificity of the mix of links and interconnections to that 'beyond'. Places viewed this way are open and porous. (1994: 5)

Edinburgh in these novels is evoked in the midst of such a process of opening, home to incomers and migrants, "others" from "beyond" whose stories can now take their place in its representational territory. In a period dominated by the populist re-imagining of spatial boundaries as controlled, fixed and stable, The Other Mrs Walker and Goblin demonstrate the dynamic instability of space and its entwined and entwining relation with the volatile and precarious social relations born out of traumatic histories. In contrast to a Brexitcircumscribed desire to return to a simplified, heroic version of the past, Edinburgh's portrayal in these contemporaneous novels holds past and present in productive relation to facilitate a desire to turn to a future of more mobile narratives of interrelation and connectedness rather than the fixed dimensions of myth. They are suggestively gesturing to an opening out of Scottish opinion and imagination.

\section{References}

Calder, Angus (1991). The Making of the Myth of the Blitz. The Guardian, 19 August, 30.

Dundas, Ever (2017). Goblin. Glasgow: Saraband.

Eaglestone, Robert, ed. (2018) Brexit and Literature: Critical and Cultural Responses. Abingdon and New York: Routledge.

Gardiner, Michael (2018). Brexit and the Aesthetics of Anachronism. In Eaglestone, Robert, ed., 105-117.

Jones, Caroline (2015). Mapping Edinburgh. In Szuba, Monica, ed., 45-58. 
Kean, Hilda (2013). Interviewed in The Little-Told Story of the Massive WWII Pet Cull. BBC News Website, 12 October. www.bbc.co.uk/news/magazine-24478532.

Kean, Hilda (2017). The Great Cat and Dog Massacre: The Real Story of World War Two's Unknown Tragedy. Chicago: University of Chicago Press.

Kelsey, Darren (2013). The Myth of the "Blitz Spirit" in British Newspaper Responses to the July 7 Bombings. Social Semiotics 23.1: 83-99.

Kirkham, Pat and David Thomas, eds. (1995). War Culture: Social Change and Changing Experience in World War Two. London: Lawrence and Wishart.

Massey, Doreen (1994). Space, Place and Gender. Cambridge: Polity Press.

Miller, Karl, ed. (1970). Memoirs of a Modern Scotland. London: Faber and Faber.

O'Toole, Fintan (2019). Heroic Failure: Brexit and the Politics of Pain. London: Head of Zeus.

Panayi, Panikos (1995). Immigrants, Refugees, the British State and Public Opinion during World War Two. In Kirkham, Pat and David Thomas, eds., 201-208.

Paulson-Ellis, Mary (2017 [2016]). The Other Mrs Walker. London: Picador.

Ponting, Clive (1990). 1940: Myth and Reality. Reading: Cox and Wyman.

Spark, Muriel (1970). What Images Return. In Miller, Karl, ed., 151-153.

Spark, Muriel (2000 [1961]). The Prime of Miss Jean Brodie. London: Penguin.

Szuba, Monika, ed. (2015). Boundless Scotland: Space in Contemporary Scottish Fiction. Gdańsk: Wydawnictwo Uniwersytetu Gdańskiego. 